\title{
Congenital Coronary Artery Abnormality
}

National Cancer Institute

\section{Source}

National Cancer Institute. Congenital Coronary Artery Abnormality. NCI Thesaurus. Code C84477.

A cong enital condition referring to defects of the course and structure of the coronary arteries. 